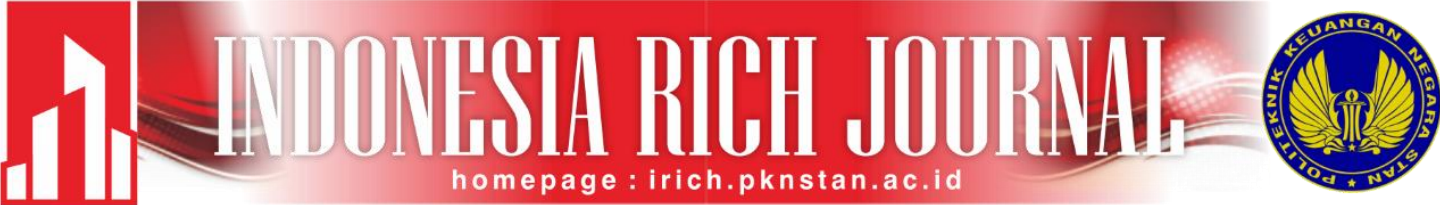

\section{ANALISIS OPTIMALISASI EKS BMN IDLE \\ (Studi Kasus Eks BMN Idle Berupa Tanah Dan Bangunan Rumah Negara Golongan II di Jl. Letjend Suprapto No. 31 Jember)}

\begin{tabular}{|c|c|}
\hline \multicolumn{2}{|r|}{$\begin{array}{c}\text { Riska Lailatul Fitri }^{1} \text { dan Doni Triono, S.E., M.M. } \\
\text { Politeknik Keuangan Negara STAN }\end{array}$} \\
\hline INFORMASI ARTIKEL & ABSTRAK \\
\hline
\end{tabular}

File Diterima:

[01 Juni 2020]

Revisi:

[10 Juni 2020]

Diterima:

[20 Juni 2020]

KATA KUNCl:

Optimalisasi, Eks BMN Idle, HBU, Pemanfaatan
Idle state property is an opportunity as well as a challenge for an asset manager. Opportunity because a good utilization pattern will generate revenue for the country, it is also called a challenge because in practice it requires quite complex research, the ability to interact with investors, as well as adjustments to the binding of the Idle state property to regulations. In Jember Regency, there are 13 units of Idle state property in the form of land and /or buildings in non-utilization status. Some of these assets have high potential value because they are located in strategic areas, one of them is on Jalan Letjend Suprapto Number 31 Jember. To find out the potential of these assets, the authors conduct market analysis and financial analysis to form the Highest and Best Use of the optimization object. The results of the analysis show that the alternative development that reflects Highest and Best Use of the optimization object is a shophouses building. After the Highest and Best Use is known, the writer identifies the form of utilization that best suits the type of development. Based on the identification, it is determined that the most appropriate form of utilization is Kerja Sama Pemanfaatan (KSP). This form of utilization will result in state revenue in the form of permanent contributions and profit sharing during the KSP period, as well as shophouses and facilities at the end of the KSP period.

BMN idle merupakan peluang sekaligus tantangan bagi seorang Asset Manager. Sebagai peluang karena pola pemanfaatan yang baik akan menghasilkan penerimaan bagi negara, juga disebut sebagai tantangan karena dalam prakteknya diperlukan research yang cukup kompleks, kemampuan berinteraksi dengan investor, serta penyesuaian atas keterikatan BMN idle pada peraturan. Di Kabupaten Jember terdapat 13 unit aset Eks BMN idle berupa tanah dan/atau bangunan dalam status tanpa pemanfaatan. Beberapa dari aset tersebut memiliki potensi nilai yang tinggi karena terletak di kawasan strategis, salah satunya Eks BMN Idle di Jalan Letjend Suprapto No. 31 Jember. Untuk mengetahui potensi aset tersebut, penulis melakukan analisis pasar dan analisis keuangan sehingga terbentuk Higest And Best Use (HBU) atas objek optimalisasi. Hasil analisis menunjukkan bahwa alternatif pengembangan yang mencerminkan HBU objek optimalisasi adalah gedung pertokoan (ruko). Setelah HBU objek optimalisasi diketahui, penulis mengidentifikasi bentuk pemanfaatan yang paling sesuai dengan tipe pengembangan. Berdasarkan idenitifikasi tersebut, ditentukan bahwa bentuk pemanfaatan yang paling sesuai adalah Kerja Sama Pemanfaatan (KSP). Bentuk pemanfaatan ini akan menghasilkan penerimaan negara berupa kontribusi tetap dan Profit Sharing selama masa KSP, serta bangunan ruko dan fasilitasnya di akhir masa KSP. 


\section{PENDAHULUAN}

\subsection{Latar Belakang}

Optimalisasi aset untuk mendukung Anggaran Pendapatan dan Belanja Negara (APBN) menjadi salah satu isu hangat di tengah upaya pemerintah dalam meningkatkan Penerimaan Negara. Untuk itu, Direktorat Jenderal Kekayaan Negara (DJKN) sebagai pelaksana fungsional atas kewenangan dan tanggungjawab Kementerian Keuangan selaku pengelola Barang Milik Negara (BMN) mulai gencar melakukan optimalisasi terhadap $\mathrm{BMN}$, terutama pada $\mathrm{BMN}$ idle dan Eks $\mathrm{BMN}$ idle. $\mathrm{BMN}$ idle adalah BMN berupa tanah dan/atau bangunan yang tidak digunakan untuk menyelenggarakan tugas dan fungsi Kementerian/Lembaga (K/L). Sedangkan Eks BMN idle adalah BMN idle yang telah diserahkan pada pengelola barang.

Kantor Pelayanan Kekayaan Negara dan Lelang (KPKNL) Kabupaten Jember merupakan salah satu unit vertikal DJKN yang saat ini bertangung jawab atas pengelolaan 5 unit Eks BMN idle berupa tanah dan bangunan di Wilayah Kabupaten Jember, kelima unit Eks BMN idle tersebut berada dalam status tanpa pemanfaatan sejak diserahkan pada tahun 2013 dan 2016. Beberapa diantara aset tersebut berpotensi menghasilkan penerimaan negara yang cukup tinggi karena berada di lokasi yang strategis, salah satunya adalah Eks BMN idle di Jalan Letjend Suprapto Nomor 31 Jember. Di samping itu, target Penerimaan Negara Bukan Pajak (PNBP) yang harus dicapai oleh KPKNL Kabupaten Jember sejak tahun 2016 mengalami peningkatan yang cukup signifikan. Di tahun 2020 sendiri, total realisasi PNBP KPKNL Kabupaten Jember per mei 2020 masih cukup jauh dari target anggaran yang ditetapkan oleh Kantor Pusat DJKN. Realisasi PNBP KPKNL Kabupaten Jember pada bulan Januari hingga Mei Tahun 2020 berada pada angka 6,42\% dari target capaian total, atau sebesar Rp1,036,367,874,dari target sebesar Rp16,136,500,000,-. Untuk menjawab tantangan akan tingginya gap realisasi tersebut, diperlukan optimalisasi terhadap seluruh $\mathrm{BMN}$, termasuk BMN Eks BMN idle di Wilayah Kerja KPKNL Kabupaten Jember.

Berdasarkan uraian di atas, penulis tertarik untuk melakukan analisis optimalisasi terhadap eks BMN idle serta mengestimasi bentuk pemanfaatan yang sesuai dengan potensi optimal eks BMN idle tersebut. Adapun objek optimalisasi adalah eks BMN idle berupa Tanah dan Bangunan Rumah Negara Golongan II seluas $370 \mathrm{~m}^{2}$ yang terletak di Jalan Letjend Suprapto, Kecamatan Sumbersari, Kabupaten Jember. Aset tersebut sebelumnya merupakan BMN idle dibawah tanggung jawab Badan Pengawasan Keuangan dan Pembangunan (BPKP) Provinsi Jawa Timur selaku pengguna barang. Hasil analisis optimalisasi ini akan dituangkan dalam artikel yang diberi judul "Analisis Optimalisasi Eks BMN Idle (Studi Kasus Eks BMN Idle Berupa Tanah Dan Bangunan Rumah Negara Golongan II di Jl. Letjend Suprapto No. 31 Jember)".

\subsection{Identifikasi Masalah}

1) Salah satu solusi untuk mengurangi gap antara target dan realisasi PNBP di KPKNL Jember adalah dengan jalan optimalisasi aset Eks BMN idle. Untuk mendapatkan hasil yang maksimal, perlu diketahui penggunaan terbaik (optimal) atas objek optimalisasi.

2) Setelah mengetahui penggunaan terbaik suatu properti, perlu juga diketahui pola pemanfaatan terbaiknya. Dalam pasal 27 Peraturan Pemerintah nomor 27 Tahun 2014 Tentang Pengelolaan Barang Milik Negara/Daerah, dikenal beberapa bentuk pemanfaatan dengan masing-masing karakteristik yang berbeda. Diperlukan pola pemanfaatan yang sesuai dengan kondisi objek optimalisasi agar menghasilkan keuntungan yang maksimal, sehingga harus dilakukan identifiksi karakteristik objek optimalisasi yang kemudian akan dibandingkan dengan karakteristik masingmasing bentuk pemanfaatan.

\subsection{Tujuan Penelitian}

1) Mengetahui penggunaan terbaik (optimal) atas aset eks BMN idle berupa Tanah dan Bangunan Rumah Negara Golongan II melalui proses optimalisasi.

2) Mengetahui bentuk pemanfaatan yang sesuai dengan penggunaan optimal objek optimalisasi.

\section{KERANGKA TEORI}

\subsection{Pemanfaatan Eks BMN Idle}

Eks BMN idle adalah BMN idle yang telah diserahkan kepada pengelola barang berdasarkan berita acara serah terima. Pengelola barang bertanggung jawab untuk melakukan pengawasan, pengendalian, pengamanan dan pemeliharaan terhadap BMN eks BMN idle, serta menyusun dan mengelola anggaran pengamanan dan pemeliharaan eks BMN idle. Selain itu, pengelola barang juga memiliki wewenang untuk melakukan penetapan status penggunaan, pemanfaatan, pemindahtanganan, dan penghapusan BMN.

Pemanfaatan merupakan pendayagunaan BMN yang tidak digunakan untuk penyelenggaraan tugas dan fungsi Kementerian/Lembaga dan/atau optimalisasi BMN dengan tidak mengubah status kepemilikan. Berdasarkan pasal 27 Peraturan Pemerintah nomor 27 Tahun 2014 Tentang 
Pengelolaan Barang Milik Negara/Daerah, bentuk pemanfaatan BMN terdiri:

1) Sewa

Sewa yaitu pemanfaatan BMN oleh pihak lain dalam jangka waktu tertentu dan menerima imbalan uang tunai. BMN dapat disewakan pada pihak lain dengan jangka waktu paling lama 5 tahun dan dapat diperpanjang. Hasil Sewa Barang Milik Negara merupakan penerimaan negara dan seluruhnya wajib disetorkan ke rekening Kas Umum Negara sebagai Penerimaan Negara Bukan Pajak (PNBP).

2) Pinjam Pakai

Pinjam Pakai yaitu penyerahan penggunaan barang dari Pemerintah Pusat ke Pemerintah Daerah dalam jangka waktu tertentu tanpa menerima imbalan dan setelah jangka waktu tersebut berakhir diserahkan kembali kepada Pengelola Barang/Pengguna Barang. Pinjam Pakai Barang Milik Negara/Daerah dilaksanakan antara Pemerintah Pusat dan Pemerintah Daerah atau antar Pemerintah Daerah dalam rangka penyelenggaraan pemerintahan. Jangka waktu Pinjam Pakai Barang Milik Negara/Daerah paling lama 5 tahun dan dapat diperpanjang 1 kali.

3) Kerja Sama Pemanfaatan (KSP)

Kerja Sama Pemanfaatan (KSP) yaitu pendayagunaan BMN oleh pihak lain dalam jangka waktu tertentu dalam rangka peningkatan Penerimaan Negara Bukan Pajak (PNBP) dan sumber pembiayaan lainnya. Kerja sama pemanfaatan Barang Milik Negara/Daerah (BMN/D) dengan pihak lain dilaksanakan dalam rangka mengoptimalkan daya guna dan hasil guna BMN/D serta meningkatkan Penerimaan Negara (untuk BMN) dan Penerimaan daerah (untuk BMD).

4) Bangun Guna Serah atau Bangun Serah Guna (BGS/BSG)

Bangun Guna Serah (BGS) adalah Pemanfaatan BMN berupa tanah oleh pihak lain dengan cara mendirikan bangunan dan/atau sarana berikut fasilitasnya, kemudian didayagunakan oleh pilain tersebut dalam jangka waktu tertentu yang telah disepakati, untuk selanjutnya diserahkan kembali tanah beserta bangunan dan/atau sarana berikut fasilitasnya setelah berakhirnya jangka waktu. Sementara Bangun Serah Guna (BSG) adalah Pemanfaatan BMN berupa tanah oleh pihak lain dengan cara mendirikan bangunan dan/atau sarana berikut fasilitasnya, dan setelah selesai pembangunannya diserahkan untuk didayagunakan oleh pihak lain tersebut dalam jangka waktu tertentu yang disepakati.

5) Kerja Sama Penyediaan Infrastruktur (KSPI)

Kerja Sama Penyediaan Infrastruktur (KSPI) adalah kerja sama antara Pemerintah dan Badan
Usaha untuk kegiatan penyediaan infrastruktur sesuai dengan ketentuan peraturan perundangundangan.

\subsection{Optimalisasi Eks BMN Idle}

Optimalisasi aset merupakan proses kerja dalam Manajemen Aset yang bertujuan untuk mengoptimalkan potensi fisik, lokasi, nilai, jumlah/volume, legal, dan nilai ekonomi yang dimiliki oleh aset tersebut (Siregar, 2004). Siregar juga mengungkapkan bahwa optimalisasi dapat dilakukan melalui Highest and Best Use Analysis, dengan memaksimalkan Ketersediaan Aset (Maximize Asset Availability), Memaksimalkan Penggunaan Aset (Maximize Asset Utilization), dan Meminimalkan Biaya Kepemilikan (Minimize Cost of Ownership).

\subsection{Analisis Highest and Best Use}

Analisis Highest and Best Use (HBU) atau juga dikenal sebagai Penggunaan Tertinggi dan Terbaik (PTT) adalah suatu proses analisis yang bertujuan untuk menentukan penggunaan yang paling layak dan optimal atas tanah atau tanah berikut bangunan serta mendukung opini nilai. HBU mencerminkan penggunaan yang paling mungkin dan optimal dari suatu aset, yang Secara Fisik Dimungkinkan (Physically Possible), Telah Dipertimbangkan Secara Memadai, Secara Hukum Diijinkan (Legally Permissible), Secara Finansial Layak (Financially Feasible), dan Menghasilkan Nilai Tertinggi (Maximally Productive).

Berdasarkan Kode Etik Penilai Indonesia (KEPI) dan Standar Penilaian Indonesia (SPI) Edisi VII, HBU terbentuk atas analisis pasar dan analisis keuangan (Gambar 3.1). Analisis pasar properti adalah studi pengidentifikasian untuk mengetahui apakah ada permintaan dan penawaran pada suatu properti di area tertentu. Pada sisi permintaan terdapat pembeli dan penyewa real estate, sedangkan di sisi penawaran ada kompetitor real estate yang sudah membangun dan yang masih dalam perencanaan. Tahapan analisis pasar terdiri dari:

1) Analisis Produktivitas properti

a. Atribut Hukum/Legal

b. Atribut Fisik

c. Atribut Lokasi

2) Analisis Permintaan dan Penawaran

3) Analisis Objek 
Analisis HBU bergantung kepada hasil analisis pasar untuk dapat mengidentifikasi alternatif penggunaan yang paling menguntungkan dan kompetitif dari suatu properti. Setelah analisis pasar dilakukan, penilai baru dapat melakukan 4 aspek analisis HBU sebagai berikut:

\section{1) Secara Hukum Diizinkan}

Hal-hal yang harus diperhatikan oleh penilai dalam aspek ini diantaranya peruntukan area (zoning), restriksi publik atau swasta, peraturan bangunan (building codes), dan peraturan intensitas pemanfaatan maksimal di area pengembangan.

2) Secara Fisik Memungkinkan

Beberapa hal yang menjadi pertimbangan penilai dari aspek fisik antara lain ukuran, jenis tanah, topografi tanah, bentuk tanah. Fisk lahan pengembangan perlu diperhatikan karena masing masing alternatif pengembangan memerlukan karakteristik lahan yang berbeda, misalnya untuk membangun hotel diperlukan lahan yang cenderung luas, berbeda dengan pembangunan ruko atau rumah tapak minimalis.

3) Secara Keuangan Layak

Dilakukan terhadap alternatif penggunaan yang secara hukum diijinkan dan secara fisik dimungkinkan. Apabila penggunaan potensial memiliki nilai yang selaras dengan biaya dan memenuhi kedua uji di atas maka penggunaan tersebut secara finansial layak. Analisis proyeksi laba rugi dan arus kas Analisis proyeksi laba rugi dan arus kas, antara lain meliputi analisis investasi awal (initial outlay), analisis pendapatan, analisis beban, analisis capital expenditures, dan analisis kelayakan proyek.

4) Menghasilkan Produktivitas Maksimal

Dilakukan atas alternatif peruntukan yang secara fisik memungkinkan, secara legal diizinkan, dan layak secara finansial. Analisis produktivitas maksimal dilakukan untuk menentukan alternatif penggunaan yang akan memberikan nilai tanah tertinggi. Persyaratan alternatif penggunaan yang memiliki produktivitas maksimal meliputi:

a. Memiliki Net Present Value (NPV) Tertinggi

b. Memiliki Interest Rate of Return (IRR) Tertinggi

c. Memiliki Payback Periode (PP) Terpendek
Gambar 3. 1 Alur Analisis HBU Berdasarkan SPI

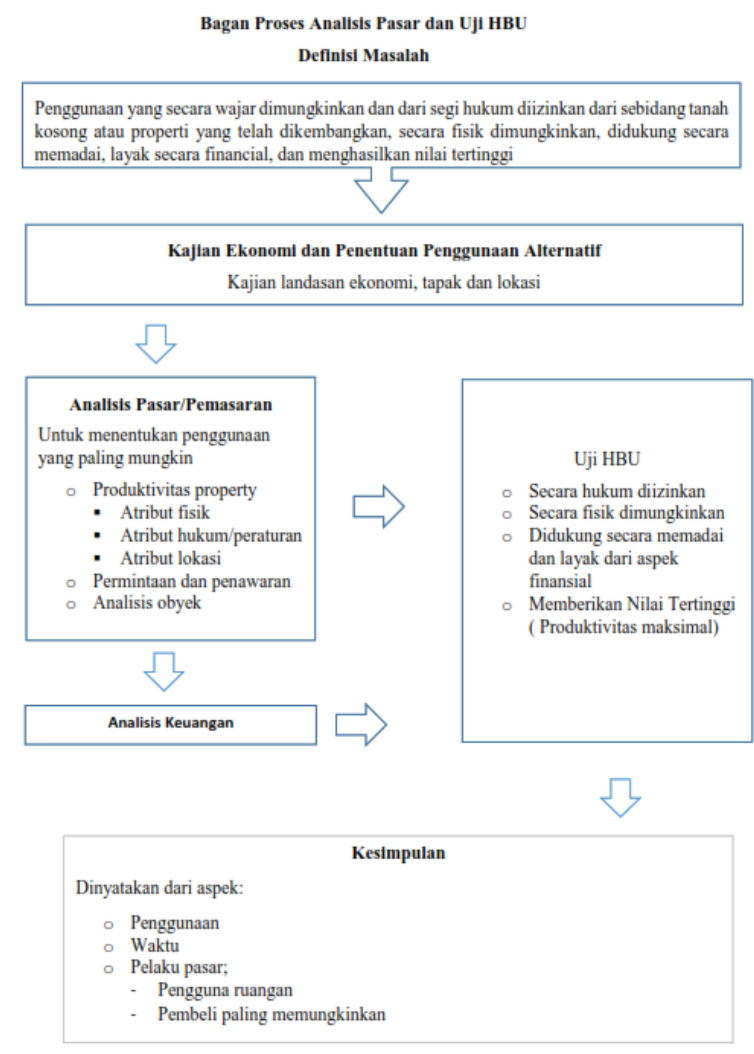

\section{METODE PENELITIAN}

Analisis ini menggunakan metode Highest Best Use Analysis untuk mengetahui penggunaan optimal atas Eks BMN idle di Jalan Letjend Suprapto (objek optimalisasi). Setelah ditentukan penggunaan paling optimal atas objek optimaliasi, dilakukan identifikasi karakter bentuk pemanfaatan yang paling sesuai dengan alternatif pengembangan terpilih. Alur analisis optimalisasi dapat dilihat pada gambar 3.2.

Adapun jenis data yang digunakan dalam karya tulis ini adalah data primer dan data sekunder. Data primer didapatkan melalui wawancara dengan narasumber dari KPKNL Kabupaten Jember mengenai data historis dan profil Eks BMN Idle, penawaran langsung dengan pemilik properti pembanding dalam penentuan harga sewa wajar objek optimalisasi, dan wawancara dengan kontraktor di wilayah Kabupaten Jember mengenai kondisi bangunan existing. Sedangkan data sekunder didapatkan melalui publikasi Badan Pusat Statistik (BPS), Bank Indonesia (BI), dan beberapa literatur lain yang dianggap kredibel. 
Gambar 3. 2 Diagram Alur Optimalisasi Eks BMN Idle

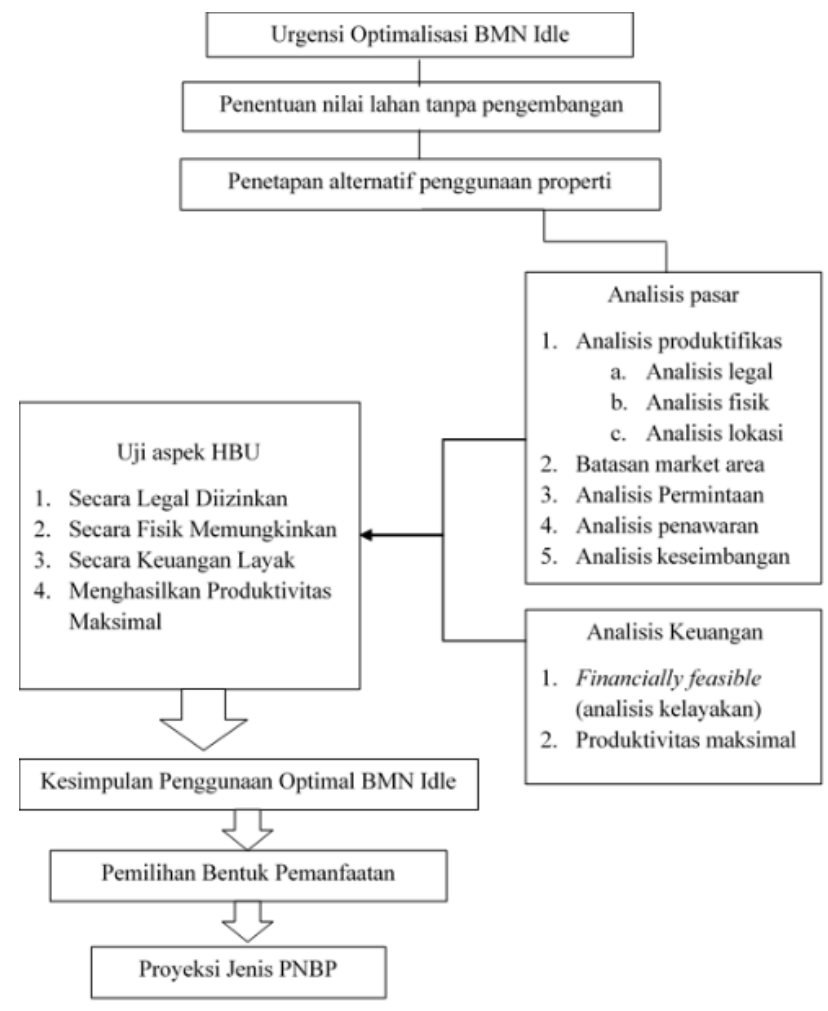

\section{HASIL PENELITIAN}

\subsection{Urgensi Optimalisasi Eks BMN Idle di Jalan Letjend Suprapto Jember}

KPKNL Kabupaten Jember saat ini mengelola 5 unit tanah idle dengan total 8 bangunan berdiri di atasnya. Berdasarkan observasi lapangan, diketahui bahwa beberapa diantara BMN tersebut berpotensi menghasilkan Penerimaan Negara yang cukup tinggi karena berada di lokasi yang strategis, salah satunya Eks BMN idle di Jalan Letjend Suprapto. Jalan Letjend Suprapto merupakan jalan lokal sekunder yang menghubungkan Pusat Kota Jember dengan beberapa kecamatan yang merupakan daerah penyangga (hinterland). Sayangnya, Eks BMN idle ini cenderung tidak terawat karena di atas lahannya berdiri bangunan bekas rumah dinas atau kantor yang berada dalam kondisi rusak berat dan tidak lagi dapat dimanfaatkan. Dalam situasi seperti inilah peran seorang Asset Manager diperlukan untuk mengoptimalkan penggunaan $\mathrm{BMN}$ idle tersebut, sehingga penurunan nilai yang lebih signifikan pada properti dapat dihindari dan negara juga berpotensi mendapatkan aliran kas dari kegiatan tersebut.

\subsection{Analisis Nilai dan Potensi Eks BMN Idle Tanpa Pengembangan}

Penilaian terhadap objek optimalisasi dilakukan untuk mengetahui nilai wajar tanah dan bangunan, sehingga nilai tersebut dapat digunakan sebagai dasar perbandingan terhadap alternatif pembangunan. Penilaian objek properti terbagi menjadi 2 komponen, yaitu penilaian tanah menggunakan pendekatan data pasar dan penilaian bangunan melalui pendekatan biaya dengan tools Daftar Komponen Penilaian Bangunan (DKPB). DKPB adalah suatu database yang berisikan daftar harga per meter setiap komponen bangunan berdasarkan perbedaan jenis struktur bangunan dan material bangunan. Berdasarkan proses penilaian dengan pendekatan data pasar, nilai pasar tanah optimalisasi saat ini (Tahun 2020) adalah sebesar Rp4.340.489.000,-. Sementara pada saat diserahkan pada pengelola barang (KPKNL Kabupaten Jember) di Tahun 2013, objek tersebut hanya tercatat memiliki nilai tanah sebesar Rp370.000.000,- dan nilai bangunan sebesar Rp125.525.000,-. Jika dibandingkan dengan saat ini, nilai tanah tersebut mengalami kenaikan yang sangat signifikan, yaitu sekitar 11.7 kali lipat (diperoleh dengan cara membagi nilai pasar tanah pada Tahun 2020 terhadap nilai pasar tanah tercatat pada Tahun 2013). Kenaikan ini disebabkan oleh pertumbuhan ekonomi Kabupaten Jember yang cukup pesat dan pengaruh lokasi properti yang menjadi sangat strategis dan ramai dilalui kendaraan seiring dengan adanya Jalan Lingkar Kota. Hal ini menunjukkan bahwa investasi properti di daerah Letjend Suprapto memberikan prospek yang sangat menguntungkan bagi pelaku bisnis.

Existing Building yang berdiri di atas lahan pembangunan sendiri jika dinilai pada Tahun 2020 menggunakan metode biaya seharusnya memiliki nilai $\pm R p 130.000 .000$,-. Namun karena bangunan terbengkalai tanpa perawatan selama hampir 20 tahun maka nilai riil-nya jauh lebih rendah dari estimasi nilai menggunakan metode biaya. Berdasarkan hasil observasi lapangan dan wawancara penulis dengan kontraktor bangunan di Wilayah Kabupaten Jember, disimpulkan bahwa bangunan eks idle yang terletak di Jalan Letjend Suprapto ini berada dalam kondisi rusak berat dan tidak memungkinkan untuk dimanfaatkan tanpa perombakan. Bangunan memerlukan renovasi total atau pembangunan ulang untuk dapat dimanfaatkan kembali. Maka dari itu penulis mengasumsikan bahwa Existing Building tidak memiliki nilai pasar, melainkan hanya Scrap Value.

Berdasarkan pertimbangan di atas, opsi yang paling sesuai untuk dilakukan terhadap objek optimalisasi adalah melakukan pembongkaran Existing Building kemudian lahan dikembangkan sesuai dengan penggunaan paling optimal properti yang diketahui melalui analisis Highest And Best Use. 


\subsection{Penentuan Penggunaan Alternatif}

Dalam penetapan jenis alternatif properti, dilakukan kajian ekonomi, tinjauan demografi dan observasi lapangan terhadap penggunaan lahan di sekitar objek optimalisasi. Kajian ekonomi yang dilakukan meliputi pertumbuhan ekonomi Kabupaten Jember secara makro dan mikro. Pertumbuhan ekonomi secara makro dapat diketahui melalui perubahan Produk Domestik Regional Bruto (PDRB), yaitu nilai tambah bruto seluruh barang dan jasa yang tercipta atau dihasilkan di wilayah domestik suatu negara yang timbul akibat berbagai aktivitas ekonomi dalam suatu periode tertentu tanpa memperhatikan apakah faktor produksi yang dimiliki residen atau nonresiden.

Gambar 4. 1 Laju Pertumbuhan Riil PDRB Kabupaten Jember, 2015-2019 (satuan \%)

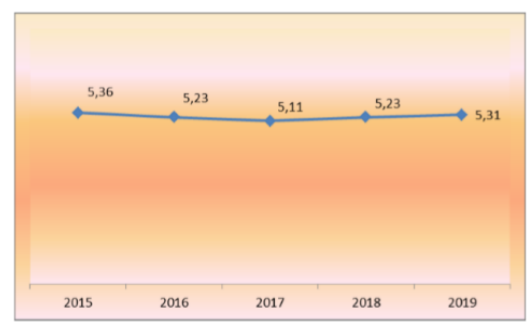

Sumber: Data BPS

Secara makro, Pertumbuhan ekonomi di Kabupaten Jember dapat dikatakan cukup stabil dalam kurun waktu 5 tahun kebelakang. Hal ini ditunjukkan oleh laju pertumbuhan riil PDRB Kabupaten Jember pada Tahun 2015 hingga Tahun 2019 yang berada dalam kisaran angka $5.11 \%$ hingga 5.36\%. Sementara secara mikro, masih terdapat kesenjangan ekonomi antara kecamatan di daerah sekitar Pusat Kota dengan daerah yang jauh dari Pusat Kota. Kecamatan dengan kategori maju dan cepat tumbuh di Kabupaten Jember adalah Kecamatan Kaliwates, Sumbersari, dan Patrang.

Berdasarkan data publikasi BPS, selama beberapa tahun terakhir jumlah penduduk di Kabupaten Jember mengalami tren peningkatan. Di Tahun 2019 jumlah penduduk mencapai 2.450 .668 jiwa, sehingga kepadatan penduduk mencapai \pm 744 jiwa $/ \mathrm{km}^{2}$. Walaupun begitu, laju pertumbuhan penduduk Kabupaten Jember dalam periode waktu tiga tahun terakhir mengalami tren yang melambat.
Gambar 4. 2 Jumlah Penduduk Kabupaten Jember

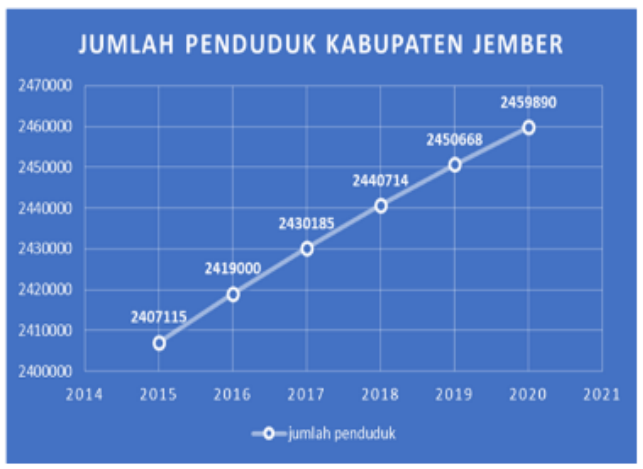

Sumber: Diolah dari data BPS

Melalui observasi lapangan, diketahui bahwa penggunaan lahan di jalan pada bagian depan properti adalah komersial, sedangkan di bagian belakang properti adalah residensial. Jenis properti komersial yang berkembang di sekitar objek optimalisasi adalah toko dan ruko yang menjual beragam kebutuhan mulai dari makanan, material bangunan, butik, dan sejenisnya. Selain toko dan ruko, terdapat juga 1 hotel non-bintang serta beberapa Kantor Cabang Perusahaan Swasta dan Pemerintah. Sedangkan jenis properti residensial yang berada di sekitar objek optimalisasi adalah rumah tinggal tapak yang rata-rata dihuni oleh satu keluarga. Kawasan pemukiman ini terletak di belakang objek optimalisasi, tepatnya di Jalan Letjend Suprapto gang $1 \mathrm{~A}$, dan tidak berhadapan langsung dengan jalan raya.

Berdasarkan analisis terhadap demografi, kajian ekonomi, serta penggunaan lahan di sekitar objek optimalisasi, alternatif properti yang dapat dikembangkan yaitu Retail Space, Office Property, dan Housing Unit.

\subsection{Analisis pasar}

\subsubsection{Analisis Produktivitas}

\subsubsection{Aspek Legal}

Berdasarkan Pasal 11 ayat 2 Peraturan Daerah Kabupaten Jember Nomor 1 Tahun 2015 Tentang Rencana Tata Ruang Wilayah Kabupaten Jember Tahun 2015 - 2035, Kecamatan Sumbersari bersama dengan Kecamatan Kaliwates dan Patrang termasuk pada daerah Pusat Kegiatan Wilayah (PKW) dengan fungsi pengembangan utama sebagai Pusat Pemerintahan, Pusat Perdagangan dan Jasa, Pusat Pendidikan, serta Pusat Kesehatan. Dijelaskan lebih lanjut melalui Peraturan Daerah tersebut pada pasal 50 ayat $4 \mathrm{~b}$ bahwa kawasan permukiman perkotaan dapat tersebar di seluruh kawasan perkotaan dengan memperhitungkan daya tampung dan daya dukung 
Studi Kasus Eks BMN Idle Berupa Tanah Dan Bangunan Rumah

Negara Golongan II di J1. Letjend Suprapto No. 31 Jember)

Riska Lailatul Fitri ${ }^{1}$ dan Doni Triono, S.E., M.M. ${ }^{2}$

perkembangan penduduk, sarana, serta prasarana yang dibutuhkan.

Pengembangan suatu lahan dibatasi dengan peraturan tata guna lahan yang ditetapkan oleh Pemerintah Daerah setempat, peraturan tersebut terdiri dari pembatasan sempadan dan intensitas pemanfaatan lahan. Berikut adalah luas tanah yang dapat dikembangkan setelah mempertimbangkan ketentuan sempadan yang berlaku di lokasi properti:

Tabel 4. 1 Perhitungan Penghitungan Luas Efektif Pengembangan

\begin{tabular}{|c|c|c|}
\hline Kategori & Luas & Perhitungan \\
\hline Luas Tanah $\left(\mathrm{m}^{2}\right)$ & 370 & \\
\hline $\begin{array}{l}\text { Garis Sempadan } \\
\text { Bangunan (GSB) }\end{array}$ & & \\
\hline Depan (m) & 3 & $3 \times 15.1=45,3 \mathrm{~m}^{2}$ \\
\hline Belakang (m) & 1,5 & $\begin{array}{l}1.5 \times(15.1 m-3 m) \\
=18,15 m^{2}\end{array}$ \\
\hline Samping (m) & 1,5 & $\begin{array}{l}2 \times 1.5 \times(24.5 m-3 m) \\
=64,5 m^{2}\end{array}$ \\
\hline Total & & $127,95 \mathrm{~m}^{2}$ \\
\hline Luas Efektif & & $\begin{array}{l}370 \mathrm{~m} 2-127,95 \mathrm{~m}^{2} \\
=242,05 \mathrm{~m}^{2}\end{array}$ \\
\hline
\end{tabular}

Sedangkan Ketentuan intensitas pemanfaatan ruang di Kabupaten Jember adalah sebagai berikut:

Tabel 4. 2 Perhitungan Intensitas Pemanfaatan Ruang Maksimal Kec. Sumbersari

\begin{tabular}{|l|c|c|}
\hline \multicolumn{1}{|c|}{ Uraian } & $\begin{array}{c}\text { Ketentuan } \\
\text { Maksimal }\end{array}$ & $\begin{array}{c}\text { Intensitas } \\
\text { Pemaanfaatan } \\
\text { Maksimal }\end{array}$ \\
\hline $\begin{array}{l}\text { Koefisien Dasar } \\
\text { Bangunan (KDB) }\end{array}$ & $70 \%$ & $\begin{array}{l}70 \% \times 370 \mathrm{~m}^{2} \\
=259 \mathrm{~m}^{2}\end{array}$ \\
\hline $\begin{array}{l}\text { Koefisien Lantai } \\
\text { Bangunan (KLB) }\end{array}$ & $180 \%$ & $\begin{array}{l}180 \% \times 370 \mathrm{~m}^{2} \\
=666 \mathrm{~m}^{2}\end{array}$ \\
\hline $\begin{array}{l}\text { Ketinggian } \\
\text { Bangunan }\end{array}$ & 4 lantai & $\begin{array}{l}\frac{666 \mathrm{~m}^{2}}{259 \mathrm{~m}^{2}} \\
=2,57 \text { lantai }^{2} \\
\approx 2 \text { lantai }\end{array}$ \\
\hline $\begin{array}{l}\text { Koefisien Dasar } \\
\text { Hijau (KDH) }\end{array}$ & $30 \%$ & $\begin{array}{l}30 \% \times 370 \mathrm{~m}^{2} \\
=111 \mathrm{~m}^{2}\end{array}$ \\
\hline
\end{tabular}

Tabel 4. 3 Perhitungan Intensitas Pemanfaatan Ruang Properti

\begin{tabular}{|l|c|l|}
\hline \multicolumn{1}{|c|}{ Uraian } & $\begin{array}{c}\text { Intensitas } \\
\text { Pemanfaatan } \\
\text { Objek }\end{array}$ & \multicolumn{1}{c|}{ Keterangan } \\
\hline $\begin{array}{l}\text { Luas lantai } \\
\text { dasar }\end{array}$ & $242 \mathrm{~m}^{2}$ & $\begin{array}{l}\text { Disesuaikan dengan } \\
\text { luas efektif lahan. }\end{array}$ \\
\hline $\begin{array}{l}\text { Luas total } \\
\text { bangunan }\end{array}$ & $\begin{array}{l}242 \mathrm{~m} 2 \times 2 \\
=484 \mathrm{~m} 2\end{array}$ & $\begin{array}{l}\text { Intensitas } \\
\text { pemanfaatan } \\
\text { maksimum adalah 2 } \\
\text { lantai }\end{array}$ \\
\hline $\begin{array}{l}\text { Tinggi } \\
\text { bangunan }\end{array}$ & 2 lantai & $\begin{array}{l}\text { Tinggi masing- } \\
\text { masing lantai } \\
\text { disesuaikan dengan } \\
\text { standar asumsi } \\
\text { DKPB. }\end{array}$ \\
\hline $\begin{array}{l}\text { Luas daerah } \\
\text { hijau }\end{array}$ & $\begin{array}{l}370 \mathrm{~m} 2-242 \mathrm{~m} 2 \\
=128 \mathrm{~m} 2\end{array}$ & $\begin{array}{l}\text { Daerah yang tidak } \\
\text { dibangun karena } \\
\text { ketentuan GSB } \\
\text { dijadikan zona } \\
\text { hijau. }\end{array}$ \\
\hline
\end{tabular}

Tabel 4. 4 Identifikasi Kesesuaian Intensitas Pemanfaatan Maksimal Dengan Intensitas Pemanfaatan Properti

\begin{tabular}{|c|c|c|c|} 
Uraian & $\begin{array}{c}\text { Intensitas } \\
\text { Pemanfaatan } \\
\text { Maks. }\end{array}$ & $\begin{array}{c}\text { Intensitas } \\
\text { Pemanfaatan } \\
\text { Objek }\end{array}$ & Keterangan \\
\hline KDB & $\leq 259 \mathrm{~m}^{2}$ & $242 \mathrm{~m}^{2}$ & Memenuhi \\
\hline KLB & $\leq 666 \mathrm{~m}^{2}$ & $484 \mathrm{~m}^{2}$ & Memenuhi \\
\hline Ketinggian & $\leq 2$ Lantai & 2 Lantai & Memenuhi \\
\hline $\mathrm{KDH}$ & $\geq 111 \mathrm{~m}^{2}$ & $128 \mathrm{~m}^{2}$ & Memenuhi \\
\hline
\end{tabular}

Gambar 4. 3 Illustrasi Lahan Pengembangan

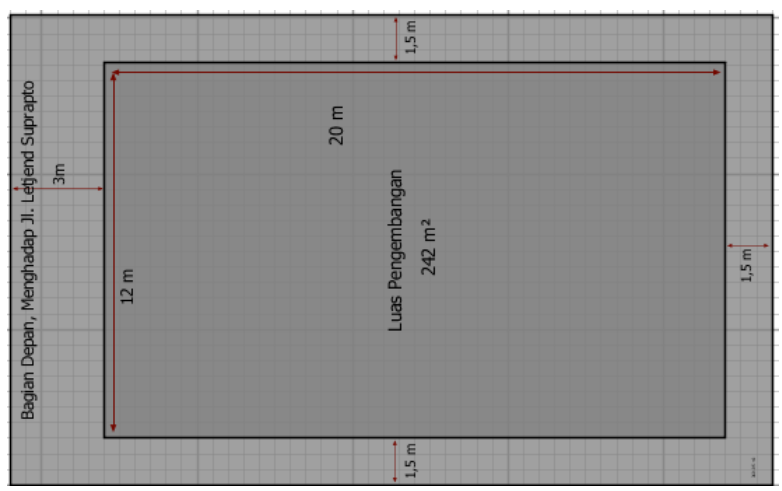

4.4.1.2 Aspek Fisik

Karakteristik Lahan Optimalisasi

\begin{tabular}{|l|l|}
\hline Ukuran & \multicolumn{1}{|c|}{$15,1 \mathrm{~m} \times 24,5 \mathrm{~m}$} \\
\hline Bentuk & $\begin{array}{l}\text { Persegi panjang. Bentuk ini } \\
\text { menguntungkan karena lebih mudah } \\
\text { dibangun dari pada lahan yang } \\
\text { berbentuk tidak teratur. }\end{array}$ \\
\hline Topografi & Datar \\
\hline Jenis Tanah & $\begin{array}{l}\text { Jenis Tanah dari objek optimalisasi } \\
\text { adalah latosol, memiliki ketahanan }\end{array}$ \\
\hline
\end{tabular}


(Studi Kasus Eks BMN Idle Berupa Tanah Dan Bangunan Rumah Negara Golongan II di J1. Letjend Suprapto No. 31 Jember)

Riska Lailatul Fitri ${ }^{1}$ dan Doni Triono, S.E., M.M. ${ }^{2}$

\begin{tabular}{|l|l|}
\hline & $\begin{array}{l}\text { yang cukup kuat terhadap } \\
\text { kemungkinan erosi. }\end{array}$ \\
\hline $\begin{array}{l}\text { Slope/kemiri } \\
\text { ngan/topogr } \\
\text { afi }\end{array}$ & $\begin{array}{l}\text { Properti objek berada di Kecamatan } \\
\text { Sumbersari yang diketahui memiliki } \\
\text { kemiringan (topografi) 0-2 }{ }^{\circ} \text {. Selain } \\
\text { itu, properti objek memiliki } \\
\text { ketinggian yang sejajar dengan jalan } \\
\text { raya di sekitarnya sehingga sangat } \\
\text { jarang terjadi banjir. }\end{array}$ \\
\hline $\begin{array}{l}\text { Tahun } \\
\text { Penyerahan }\end{array}$ & 2013 \\
\hline Nilai Buku & $\begin{array}{l}\text { Rp370.000.000,00 (Tiga Ratus Tujuh } \\
\text { Puluh Juta Rupiah) }\end{array}$ \\
\hline $\begin{array}{l}\text { Kondisi } \\
\text { Tanah }\end{array}$ & $\begin{array}{l}\text { Kondisi tanah saat ini kurang terawat } \\
\text { dan banyak ditumbuhi tanaman liar. }\end{array}$ \\
\hline & \\
\hline $\begin{array}{l}\text { Gambar } \\
\text { Situasi }\end{array}$ & \\
\hline
\end{tabular}

\subsubsection{Aspek Lokasi}

\begin{tabular}{|c|c|}
\hline Deskripsi & Uraian \\
\hline $\begin{array}{l}\text { Akses } \\
\text { Menuju } \\
\text { Objek }\end{array}$ & $\begin{array}{l}\text { Sebagai jalan lokal sekunder di } \\
\text { Wilayah Kabupaten Jember, Jalan } \\
\text { Letjend Suprapto sangat mudah } \\
\text { diakses oleh kendaraan roda dua, } \\
\text { roda empat, dan kendaraan } \\
\text { berkapasitas rendah lainnya. Namun, } \\
\text { kendaraan dengan kapasitas muatan } \\
\text { tinggi seperti truk, bus, container, } \\
\text { dan sebagainya dilarang melintasi } \\
\text { jalan ini, karena jalan ini langsung } \\
\text { mengarah pada Pusat Kota Jember. } \\
\text { Hal ini menunjukkan ketidaksesuaian } \\
\text { pengembangan untuk industri di } \\
\text { lahan optimalisasi, karena jenis } \\
\text { usaha tersebut memerlukan } \\
\text { distribusi barang menggunakan } \\
\text { kendaraan dengan kapasitas muatan } \\
\text { berat. }\end{array}$ \\
\hline $\begin{array}{c}\text { Lingkage } \\
\text { (Keterkaitan) }\end{array}$ & $\begin{array}{l}\text { Lokasi objek properti di Jalan Letjend } \\
\text { Suprapto tergolong strategis karena } \\
\text { memiliki lingkage langsung menuju } \\
\text { Central Bussiness District (CBD). }\end{array}$ \\
\hline
\end{tabular}

\subsubsection{Kesimpulan Analisis Produktivitas}

Berdasarkan analisis produktivitas, disimpulkan bahwa jenis properti komersial yang berkembang dan memungkinkan untuk didirikan pada lahan penelitian yaitu ruko dan kantor. Sedangkan jenis properti residensial yang memungkinkan untuk dikembangkan pada lahan penelitian adalah rumah tapak.

\subsubsection{Batasan Market Area}

Objek optimalisasi terletak di Kecamatan Sumbersari. Berdasarkan tingkat populasi dan kegiatan perekonomiannya, daerah yang serupa dengan Kecamatan Sumbersari adalah Kecamatan Kaliwates dan Patrang, sehingga permintaan dan pesaing diperkirakan berasal dari daerah tersebut. Atas pertimbangan ini, maka batasan market area adalah Kecamatan Sumbersari, Kecamatan Kaliwates, dan Patrang.

\subsubsection{Analisis Permintaan}

Berdasarkan survei lapangan dan analisis pada data kepemilikan properti BPS, diketahui bahwa permintaan untuk alternatif rumah tapak menunjukkan tren yang meningkat dari tahun ke tahun sehubungan dengan terus bertambahnya jumlah penduduk di market area. Hal ini juga terjadi pada alternatif ruko yang memiliki tingkat permintaan tinggi karena lokasi objek yang strategis dan dekat dengan Central Bussiness District (CBD) serta ramai dilalui kendaraan dari berbagai wilayah. Permintaan atas properti kantorpun menunjukkan tren meningkat seiring dengan iklim usaha Kabupaten Jember yang terus berkembang.

\subsubsection{Analisis Penawaran}

Berdasarkan observasi lapangan dan data BPS, diketahui bahwa penawaran untuk properti residensial berupa rumah sewa cenderung rendah, berbanding terbalik dengan permintaan yang diproyeksikan naik. Hal ini bisa jadi disebabkan oleh harga tanah harga sewa untuk properti hunian rumah tapak sewa yang rendah. Pada properti kantor, pesaing utamanya adalah ruko, karena jenis usaha/ bisnis yang berkembang di Kabupaten Jember masih berupa Usaha Mikro, Kecil dan Menengah (UMKM) sehingga tidak membutuhkan gedung kantor dengan prestige dan image mewah. Diantara ketiga alternatif, ruko adalah alternatif dengan tingkat persaingan paling tinggi, namun masih mampu menyerap permintaan pasar, karena tingkat permintaan berasal dari 2 bidang usaha yaitu bisnis dan perdagangan.

\subsubsection{Analisis Keseimbangan}

Melalui observasi lapangan, diketahui bahwa ketiga alternatif memiliki tren permintaan yang meningkat, namun terdapat gap yang cukup tinggi dengan penawaran, sehingga ketiganya diestimasi mampu menyerap permintaan di market area. 
Tingkat hunian untuk properti ruko dan kantor berdasarkan observasi lapangan adalah sebesar $89 \%$ dan 78\%. Angka ini didapat dari rata-rata jumlah ruko/kantor yang kosong pada suatu komplek ruko/kantor. Sementara untuk rumah tapak, tingkat hunian diproyeksikan sebesar $100 \%$.

\subsubsection{Kesimpulan Alternatif Pengembangan}

Berdasarkan analisis pasar yang telah dilakukan, penulis menyusun 3 alternatif pengembangan yang meliputi:

1) Rumah Kontrakan (Sewa)

Tren pengembangan di daerah pusat kota untuk rumah tinggal adalah rumah tapak bertipe minimalis antara 1 hingga 2 lantai. Dengan demikian, pengembangan yang paling sesuai dengan luas lahan pengembangan adalah rumah minimalis bertipe 36/72 dengan luas tanah $52 \mathrm{~m}^{2}$. Rumah ini akan dibangun 2 lantai sesuai dengan ketentuan tinggi bangunan maksimal agar lahan digunakan secara efisien, sehingga luas total bangunan per unit rumah adalah $72 \mathrm{~m}^{2}$.

\section{Gambar 3. 3 Layout pengembangan rumah kontrak} (sewa)

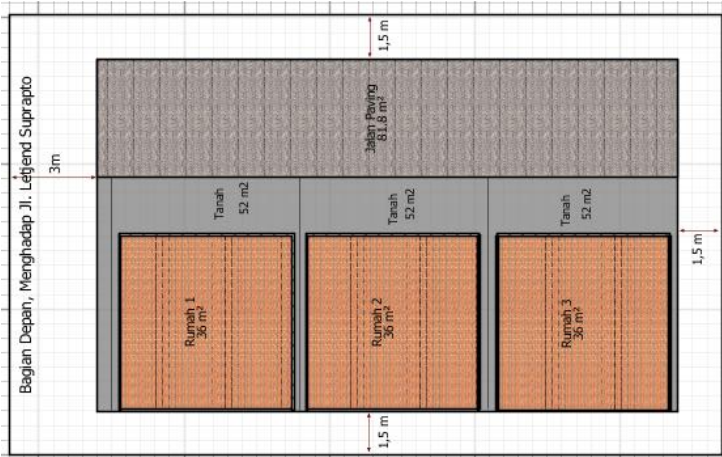

2) Ruko

Berdasarkan survei, diketahui bahwa ukuran ruko yang berkembang di sekitar objek properti memiliki luas lantai dasar $40 \mathrm{~m}^{2}-70 \mathrm{~m}^{2}$ dengan ketinggian 2 lantai. Dengan mempertimbangkan ukuran luas pengembangan efektif, penulis menyimpulkan bahwa ukuran ruko yang paling sesuai untuk dikembangkan pada lahan optimalisasi adalah ruko 2 lantai dengan luas lantai dasar $40 \mathrm{~m}^{2}$. Sehingga jumlah ruko yang maksimum dapat dibangun di atas lahan pengembangan efektif $\left(242 \mathrm{~m}^{2}\right)$ adalah sebanyak 4 unit dan masing-masing memiliki luas total $80 \mathrm{~m}^{2}$, sisa luas lahan efektif dipergunakan sebagai lahan parkir.
Gambar 3. 4 Layout pengembangan Ruko

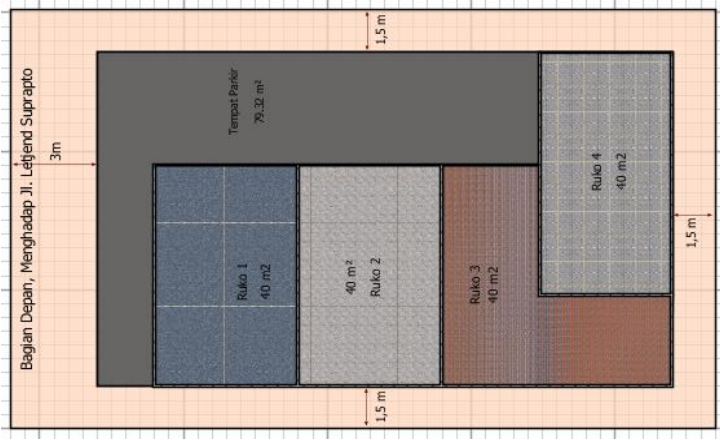

3) Kantor

Berdasarkan analisis yang dilakukan baik melalui survei secara langsung maupun online pada market area primer, penulis menyimpulkan bahwa ukuran yang paling sesuai untuk dikembangkan pada lahan pengembangan adalah kantor 2 lantai dengan luas lantai dasar per unit $56 \mathrm{~m}^{2}(14 \mathrm{~m} \times 4 \mathrm{~m})$. Sehingga unit yang maksimum dapat dibangun adalah sebanyak 3 unit kantor dengan luas total masing-masing $112 \mathrm{~m}^{2}$. Sedangkan sisa lahannya dimanfaatkan untuk lahan parkir mengingat properti jenis kantor membutuhkan lahan parkir yang cukup luas.

Gambar 3. 5 Layout pengembangan kantor

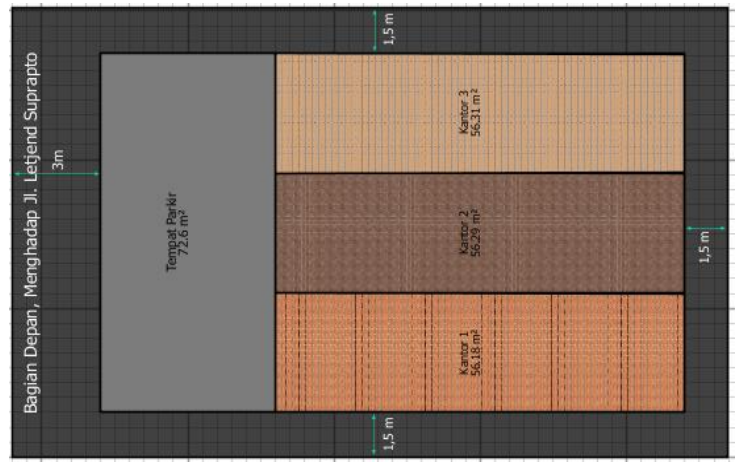

\subsection{Analisis Keuangan}

\subsubsection{Analisis Kelayakan (Financially Feasible)}

\subsubsection{Analisis Biaya Pengembangan (Initial Outlay)}

Analisis Initial Outlay dilakukan melalui pendekatan biaya dengan memanfaatkan tools DKPB Kabupaten Jember Tahun 2020. Standar material yang digunakan pada bangunan disesuaikan dengan properti sejenis yang berkembang di lokasi lahan pengembangan. Sedangkan biaya pembongkaran existing building diperoleh melalui wawancara dengan kontraktor bangunan di Kabupaten Jember. 
(Studi Kasus Eks BMN Idle Berupa Tanah Dan Bangunan Rumah

Negara Golongan II di J1. Letjend Suprapto No. 31 Jember)

Riska Lailatul Fitri ${ }^{1}$ dan Doni Triono, S.E., M.M. ${ }^{2}$

Tabel 4. 5 Rancangan Spesifikasi Bangunan

\begin{tabular}{|c|c|c|c|}
\hline \multirow{2}{*}{$\begin{array}{c}\text { Komponen } \\
\text { Bangunan }\end{array}$} & \multicolumn{3}{|c|}{ Material Bangunan } \\
\hline & $\begin{array}{c}\text { Rumah } \\
\text { Kontrakan }\end{array}$ & Ruko & Kantor \\
\hline $\begin{array}{l}\text { Struktur } \\
\text { Bawah }\end{array}$ & Batu Kali & Batu Kali & Batu Kali \\
\hline $\begin{array}{l}\text { Struktur } \\
\text { Rangka }\end{array}$ & Beton & Beton & Beton \\
\hline $\begin{array}{l}\text { Struktur } \\
\text { Atap }\end{array}$ & Beton & Beton & Beton \\
\hline Atap & $\begin{array}{c}\text { Genteng } \\
\text { Metal }\end{array}$ & $\begin{array}{c}\text { Genteng } \\
\text { Metal }\end{array}$ & $\begin{array}{c}\text { Genteng } \\
\text { Metal }\end{array}$ \\
\hline Dinding & $\begin{array}{c}\text { Bata } \\
\text { Diplester }\end{array}$ & $\begin{array}{c}\text { Bata } \\
\text { Diplester }\end{array}$ & $\begin{array}{c}\text { Bata } \\
\text { Diplester }\end{array}$ \\
\hline $\begin{array}{l}\text { Langit- } \\
\text { Langit }\end{array}$ & Eternit & Akustik & Akustik \\
\hline Lantai & $\begin{array}{c}\text { Keramik } \\
\text { KW II }\end{array}$ & $\begin{array}{c}\text { Keramik } \\
\text { KW II }\end{array}$ & $\begin{array}{c}\text { Keramik } \\
\text { KW II }\end{array}$ \\
\hline Instalasi Air & PDAM & PDAM & PDAM \\
\hline $\begin{array}{l}\text { Instalasi } \\
\text { Listrik }\end{array}$ & PLN & PLN & PLN \\
\hline $\begin{array}{l}\text { Pelapis } \\
\text { Dinding }\end{array}$ & Cat & Cat & $\begin{array}{c}\text { Cat dan } \\
\text { Kaca }\end{array}$ \\
\hline Pagar & $\begin{array}{l}\text { Pas.Beton } \\
\text { Pracetak }\end{array}$ & $\begin{array}{c}\text { Pas.Beton } \\
\text { Pracetak }\end{array}$ & $\begin{array}{c}\text { Pas.Beton } \\
\text { Pracetak }\end{array}$ \\
\hline Perkerasan & $\begin{array}{c}\text { Paving } \\
\text { Blok Tebal } \\
6 \mathrm{Cm}\end{array}$ & $\begin{array}{c}\text { Beton } \\
\text { Tidak } \\
\text { Bertulang }\end{array}$ & $\begin{array}{c}\text { Beton } \\
\text { Tidak } \\
\text { Bertulang }\end{array}$ \\
\hline
\end{tabular}

Tabel 4. 6 Biaya Pembangunan Berdasarkan DKPB (Ribu)

\begin{tabular}{|l|c|c|}
\hline Alternatif & $\begin{array}{c}\text { Biaya } \\
\text { Pembongkaran }\end{array}$ & $\begin{array}{c}\text { Biaya Pembangunan } \\
\text { Gedung }\end{array}$ \\
\hline $\begin{array}{l}\text { Rumah } \\
\text { Kontrakan }\end{array}$ & Rp12.000 & Rp778.941 \\
\hline Ruko & Rp12.000 & Rp785.478 \\
\hline Kantor & Rp12.000 & Rp 845.766 \\
\hline
\end{tabular}

\subsubsection{Analisis Biaya Operasinal dan Biaya Lain- Lain}

Beban dalam analisis ini dibagi menjadi biaya operasional dan biaya lain-lain. Biaya operasional mencakup pemasaran, perawatan bangunan (pembersihan dan pemotongan rumput), serta inspeksi instalasi listrik dan air. Sedangkan biaya lain-lain mencakup pembayaran pajak yang berlaku di bidang penyewaan properti.
Tabel 4. 7 Analisis biaya operasional dan biaya lain-lain

\begin{tabular}{|l|c|c|c|}
\hline \multicolumn{1}{|c|}{ Jenis Biaya } & $\begin{array}{c}\text { Rumah } \\
\text { Kontrakan }\end{array}$ & Ruko & Kantor \\
\hline $\begin{array}{l}\text { Pemasaran } \\
\text { Properti (Ribu) }\end{array}$ & $\mathrm{Rp2,796}$ & $\mathrm{Rp} 2,796$ & $\mathrm{Rp} 2,796$ \\
\hline $\begin{array}{l}\text { Pembersihan } \\
\text { Properti Kosong } \\
\text { (Ribu) }\end{array}$ & $\mathrm{Rp} 1,440$ & $\mathrm{Rp} 1,440$ & $\mathrm{Rp} 1,440$ \\
\hline $\begin{array}{l}\text { Inspeksi } \\
\text { Kelistrikan dan } \\
\text { Air (Ribu) }\end{array}$ & $\mathrm{Rp} 1,140$ & $\mathrm{Rp} 1,140$ & $\mathrm{Rp} 1,140$ \\
\hline PBB (Ribu) & $\mathrm{Rp5,127}$ & $\mathrm{Rp5}, 812$ & $\mathrm{Rp5,554}$ \\
\hline $\begin{array}{l}\text { Asumsi biaya } \\
\text { terhadap EGI }\end{array}$ & $15 \%$ & $10 \%$ & $10 \%$ \\
\hline $\begin{array}{l}\text { PPh Final (Atas } \\
\text { Harga Sewa) }\end{array}$ & $10 \%$ & $10 \%$ & $10 \%$ \\
\hline $\begin{array}{l}\text { PPN (Atas } \\
\text { Harga Sewa) }\end{array}$ & $10 \%$ & $10 \%$ & $10 \%$ \\
\hline
\end{tabular}

\subsubsection{Capital Expenditures}

Untuk menjaga properti agar tetap berada dalam kondisi optimal, penulis menetapkan perlunya mencadangkan dana untuk Capital Expenditures dengan asumsi sebagai berikut:

a) Pencadangan dana (Reserved Fund) dilakukan setiap tahun selama umur ekonomis bangunan.

b) Dana cadangan disisihkan dari penghasilan kotor (Effective Gross Income) pada tahun penyisihan.

c) Besaran dana dicadangakan ditetapkan sebesar 5\% dari Effective Gross Income (EGI).

d) Umur ekonomis bangunan ditetapkan sesuai standar akuntansi, yaitu 30 tahun.

e) Capital expenditures dilakukan setiap 5 tahun sekali.

\subsubsection{Analisis Pendapatan}

Aliran pendapatan diperoleh dari kegiatan penyewaan bangunan yang harga sewanya ditentukan melalui pendekatan data pasar, yaitu membandingkan masing-masing alternatif pengembangan dengan properti sejenis yang berlokasi di sekitar lahan pengembangan. Dasar nilai yang digunakan dalam pendekatan data pasar tersebut adalah nilai wajar atas sewa. Adapun objek pembanding untuk masing-masing alternatif diperoleh melalui survei lapangan dan survei online. Setelah ditentukan 3 objek pembanding untuk masing-masing alternatif, dilakukan penyesuaian (adjustment) dan rekonsiliasi nilai sebagaimana diatur dalam Standar Penilaian Indonesia (SPI). 
(Studi Kasus Eks BMN Idle Berupa Tanah Dan Bangunan Rumah Negara Golongan II di J1. Letjend Suprapto No. 31 Jember)

Riska Lailatul Fitri ${ }^{1}$ dan Doni Triono, S.E., M.M. ${ }^{2}$

Tabel 4. 8 Analisis Pendapatan

\begin{tabular}{|c|c|c|c|}
\hline Alternatif & $\begin{array}{c}\text { Rumah } \\
\text { Kontrakan }\end{array}$ & Ruko & Kantor \\
\hline $\begin{array}{c}\text { Lease Area } \\
\left(\mathrm{m}^{2}\right)\end{array}$ & 264 & 320 & 336 \\
\hline $\begin{array}{c}\text { Harga Sewa } \\
(\text { Ribu }) / \mathrm{m}^{2}\end{array}$ & $\mathrm{Rp} 232$ & $\mathrm{Rp} 477$ & $\mathrm{Rp} 354$ \\
\hline $\begin{array}{c}\text { Occupancy } \\
\text { Rate }\end{array}$ & $100 \%$ & $90 \%$ & $78 \%$ \\
\hline $\begin{array}{c}\text { Total Effective } \\
\text { Gross Income } \\
\text { (Ribu) }\end{array}$ & $\mathrm{Rp} 357,162$ & $\mathrm{Rp} 799,417$ & $\mathrm{Rp} 541,024$ \\
\hline $\begin{array}{c}\text { Total Net } \\
\text { Operating } \\
\text { Income (Ribu) }\end{array}$ & $\mathrm{Rp} 346,832$ & $\mathrm{Rp} 824,446$ & $\mathrm{Rp} 557,963$ \\
\hline
\end{tabular}

\subsubsection{Tingkat Diskonto dan Tingkat Kapitalisasi}

Sebelum melakukan proyeksi arus kas, diperlukan pennetuan tingkat diskonto dan tingkat kapitalisasi terlebih dahulu. Tingkat diskonto (discount rate) dalam karya tulis ini ditentukan dengan metode Capital Asset Pricing Model (CAPM). Risk Free Rate atau tingkat pengembalian instrumen bebas risiko diperoleh melalui rata-rata Suku Bunga 22 Bank Umum Besar di Indonesia pada bulan Januari hingga April Tahun 2020, sementara Market Risk Premium diperoleh melalui data sekunder yang berasal dari Page Damodaran dan Market Risk Premia.

Tabel 4. 9 Penghitungan Tingkat Diskonto dan Tingkat Kapitalisasi

\begin{tabular}{|l|c|c|}
\multicolumn{1}{|c|}{ Bulan } & Risk Free Rate & $\begin{array}{c}\text { Market Risk } \\
\text { Premium }\end{array}$ \\
\hline Januari & $5.70 \%$ & $2.35 \%$ \\
\hline Februari & $5.60 \%$ & $3.03 \%$ \\
\hline Maret & $5.50 \%$ & $4.55 \%$ \\
\hline April & $5.50 \%$ & $3.48 \%$ \\
\hline Rata-Rata & $5.58 \%$ & $3.35 \%$ \\
\hline Beta & \multicolumn{2}{|c|}{$\mathbf{9 . 2 0 \%}$} \\
\hline Discount Rate & \multicolumn{2}{|c|}{$6.375 \%$} \\
\hline Capitalization Rate & \multicolumn{2}{|c|}{} \\
\hline
\end{tabular}

Tingkat kapitalisasi (capitalization rate) adalah tingkat kembalian yang digunakan untuk memproyeksikan aliran kas menjadi nilai suatu properti. Tingkat kapitalisasi dalam analisis ini adalah sebesar 6,375\% dimana angka ini merupakan tingkat kupon untuk Obligasi Negara yang akan jatuh tempo pada tahun 2042. Tingkat kupon tersebut dipilih karena diasumsikan telah mencerminkan tingkat kembalian investasi properti jika dibandingkan dengan menyimpan uang dalam bentuk obligasi jangka panjang.

\subsubsection{Analisis Kelayakan}

Setelah mengetahui estimasi biaya, pendapatan, discount rate, serta tingkat kapitalisasi, penulis melakukan proyeksi kas menggunakan metode Discounted Cash Flow (DCF) dengan proyeksi waktu 5 tahun. Dalam analisis ini, diketahui bahwa ketiga alternatif pengembangan layak untuk dikembangkan karena memiliki NPV lebih dari 0 (Tabel 4.10). Artinya, penerimaan yang dihasilkan oleh usaha sewa rumah kontrakan, ruko, atau kantor lebih besar dibandingkan dengan biaya yang diperlukan untuk mengembangkan (membangun) ketiga jenis properti tersebut.

Tabel 4. 10 Analisis Kelayakan Properti

\begin{tabular}{|c|c|c|c|}
\hline Indikator & $\begin{array}{c}\text { Rumah } \\
\text { Kontrakan }\end{array}$ & Ruko & Kantor \\
\hline NPV (Juta) & Rp39 & Rp1,159 & Rp470 \\
\hline $\begin{array}{c}\text { Nilai } \\
\text { Lahan+Pengem } \\
\text { bangan (Juta) }\end{array}$ & $\mathrm{Rp4,380}$ & $\mathrm{Rp} 5,500$ & $\mathrm{Rp4,811}$ \\
\hline Kesimpulan & Layak & Layak & Layak \\
\hline
\end{tabular}

\subsubsection{Produktivitas Maksimal}

Analisis produktivitas maksimal dilakukan untuk mengetahui alternatif pengembangan yang menghasilkan keuntungan paling tinggi. Indikator yang digunakan untuk pengambilan keputusan adalah Net Present Value (NPV), Internal Rate Of Return (IRR), Payback Periode (PP), Profitability Index (PI), dan produktivitas properti. Melalui indikator tersebut diketahui bahwa alternatif ruko diproyeksikan menghasilkan NPV sebesar Rp1,159,976,342,- dengan IRR sebesar $18.02 \%$, dan PI sebesar 1.48. Sedangkan kedua alternatif lain (kantor dan rumah kontrakan) memiliki NPV di bawah ruko, IRR di bawah ruko, PP yang lambat dari ruko, dan PI lebih kecil dari ruko. Selain itu diantara ketiga alternatif ini, satu-satunya yang memiliki IRR di atas tingkat diskonto adalah alternatif ruko. Artinya alternatif pengembangan ruko menjanjikan tingkat kembalian yang lebih tinggi dibanding kedua alternatif lain.

Produktivitas properti ditentukan dengan membandingkan kenaikan nilai lahan setelah dikembangkan sesuai ketiga alternatif dengan nilai lahan dalam keadaan kosong (tanpa pengembangan). Berdasarkan perhitungan, nilai lahan tertinggi dihasilkan oleh alternatif ruko dengan nilai Rp5,500,465,341,- atau kenaikan sebesar 26,7\% dibandingkan nilai lahan tanpa pengembangan (Rp4,340,489,000,-). 
Tabel 4. 11 Analisis Produktivitas Properti

\begin{tabular}{|c|c|c|c|}
\hline Indikator & Rumah & Ruko & Kantor \\
\hline NPV (000) & Rp39,710 & Rp1,159,976 & Rp470,865 \\
\hline IRR & $0.86 \%$ & $18.02 \%$ & $8.10 \%$ \\
\hline PP & 20.578 & 6.242 & 6.881 \\
\hline PI & 0.05 & 1.48 & 0.56 \\
\hline Produktivitas & $0.9 \%$ & $26.7 \%$ & $10.8 \%$ \\
\hline
\end{tabular}

Berdasarkan pertimbangan di atas, disimpulkan bahwa objek properti memiliki produktivitas maksimal pada alternatif pengembangan sebagai ruko.

\subsection{Uji Aspek HBU}

Melalui rangkaian proses analisa penggunaan optimal properti, diketahui bahwa alternatif yang memenuhi semua kriteria HBU adalah alternatif ruko. Sehingga kesimpulan yang diperoleh dari uji HBU adalah bahwa kegunaan paling optimal untuk BMN idle berupa Tanah dan Bangunan Rumah Negara Golongan II yang terletak di Jalan Letjend Suprapto, Kecamatan Sumbersari, Kabupaten Jember adalah sebagai ruko. Pengembangan ruko pada lahan tersebut diproyeksikan menghasilkan arus kas sebesar Rp1,159,976,342,- dan nilai lahan sebesar Rp5,500,465,341,-

Tabel 4. 12 Uji Aspek HBU

\begin{tabular}{|c|c|c|c|c|}
\hline \multirow{2}{*}{ Uji Kriteria } & \multirow{2}{*}{ Kriteria } & \multicolumn{3}{|c|}{ Pemilihan Alternatif } \\
\hline & & Rumah & Ruko & Kantor \\
\hline \multirow{2}{*}{$\begin{array}{c}\text { Legally } \\
\text { Permissible }\end{array}$} & Zoning & \multirow{2}{*}{\multicolumn{3}{|c|}{ Memenuhi }} \\
\hline & $\begin{array}{c}\text { Building } \\
\text { Codes }\end{array}$ & & & \\
\hline \multirow{4}{*}{$\begin{array}{l}\text { Phisically } \\
\text { Possible }\end{array}$} & $\begin{array}{c}\text { Bentuk dan } \\
\text { Ukuran }\end{array}$ & \multirow{4}{*}{\multicolumn{3}{|c|}{ Memenuhi }} \\
\hline & Lokasi & & & \\
\hline & Aksesibilitas & & & \\
\hline & $\begin{array}{c}\text { Penggunaan } \\
\text { Lahan }\end{array}$ & & & \\
\hline \multirow{3}{*}{$\begin{array}{c}\text { Financially } \\
\text { Feasible }\end{array}$} & NPV & \multicolumn{3}{|c|}{ Memenuhi } \\
\hline & IRR & $\begin{array}{c}\text { Tidak } \\
\text { Memenu } \\
\text { hi }\end{array}$ & $\begin{array}{c}\text { Meme- } \\
\text { nuhi }\end{array}$ & $\begin{array}{c}\text { Tidak } \\
\text { Memen } \\
\text { uhi }\end{array}$ \\
\hline & PI & $\begin{array}{c}\text { Tidak } \\
\text { Memenu } \\
\text { hi }\end{array}$ & $\begin{array}{l}\text { Meme- } \\
\text { nuhi }\end{array}$ & $\begin{array}{c}\text { Tidak } \\
\text { Memen } \\
\text { uhi }\end{array}$ \\
\hline $\begin{array}{l}\text { Maximum } \\
\text { Productivity }\end{array}$ & Produktivitas & $0.91 \%$ & $26.72 \%$ & $10.9 \%$ \\
\hline
\end{tabular}

\subsection{Bentuk Pemanfaatan Yang Paling Sesuai Dengan Alternatif Pengembangan Optimal}

Menurut pasal 5 Peraturan Nomor 78/PMK.06/2014 Tentang Tata Cara Pelaksanaan Pemanfaatan Barang Milik Negara, ada 5 bentuk pemanfaatan BMN, yaitu sewa, pinjam pakai, KSP, BGS/BSG, dan KSPI. Masing-masing bentuk pemanfaatan memiliki ciri dan persayaratan yang berbeda (Gambar 4.4).

\section{Gambar 4. 4 Karakteristik Bentuk-bentuk Pemanfaatan Aset}

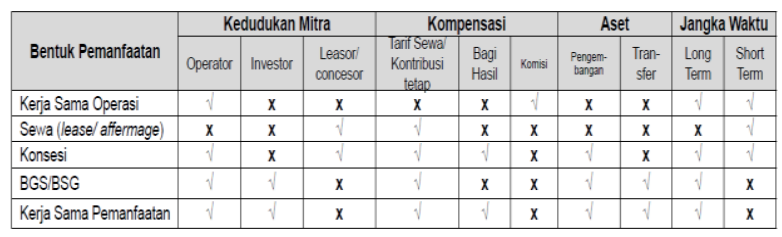

Sumber: Media Keuangan Edisi No.27 Tahun VIII / 2017

Analisis HBU pada Eks BMN idle di Jalan Letjend Suprapto menghasilkan pembangunan ruko sebagai penggunaan optimal lahan tersebut. Pembangunan ruko beserta segala fasilitasnya membutuhkan modal (initial outlay) yang besar dan dibutuhkan pengelolaan operasional secara berkala untuk menjaga kelangsungan usaha. Hal tersebut tidak dapat dilakukan oleh pengelola barang seorang diri karena bukan merupakan tugas dan fungsinya. Pengelola barang perlu bekerja sama dengan pihak ketiga yang dianggap mampu memenuhi segala kebutuhan pemanfaatan. Pengelola barang harus mempertimbangkan bentuk pemanfaatan yang sesuai dengan karakteristik pengembangan optimal, batasan hukum, serta keuntungan tertinggi yang dapat dicapai. Untuk menentukan bentuk pemanfaatan yang tepat, dilakukan analisa sebagai berikut:

Tabel 4. 13 Pemilihan Bentuk Pemanfaatan

\begin{tabular}{|l|c|c|c|c|c|}
\hline \multicolumn{1}{|c|}{ Kriteria } & Sewa & $\begin{array}{c}\text { Pinjam } \\
\text { Pakai }\end{array}$ & KSP & $\begin{array}{c}\text { BGS/ } \\
\text { BSG }\end{array}$ & KSPI \\
\hline $\begin{array}{l}\text { Optimalisasi } \\
\text { BMN Idle }\end{array}$ & $\mathbf{v}$ & $\mathbf{v}$ & $\mathbf{v}$ & $\mathbf{v}$ & $\mathbf{x}$ \\
\hline $\begin{array}{l}\text { Pengembangan } \\
\text { Lahan (Sebagai } \\
\text { Ruko) }\end{array}$ & $\mathbf{x}$ & $\mathbf{x}$ & $\mathbf{v}$ & $\mathbf{v}$ & $\mathbf{x}$ \\
\hline $\begin{array}{l}\text { Pembiayaan } \\
\text { Pengembangan }\end{array}$ & $\mathbf{x}$ & $\mathbf{x}$ & $\mathbf{v}$ & $\mathbf{v}$ & $\mathbf{\times}$ \\
\hline $\begin{array}{l}\text { Pengoperasian } \\
\text { Bangunan } \\
\text { (Menyewakan } \\
\text { Ruko) }\end{array}$ & $\mathbf{x}$ & $\mathbf{x}$ & $\mathbf{v}$ & $\mathbf{v}$ & $\mathbf{x}$ \\
\hline $\begin{array}{l}\text { Pemeliharaan } \\
\text { Gedung } \\
\text { (Perawatan Dan } \\
\text { Perbaikan)) }\end{array}$ & $\mathbf{v}$ & $\mathbf{v}$ & $\mathbf{v}$ & $\mathbf{v}$ & $\mathbf{v}$ \\
\hline Kontribusi PNBP & $\mathbf{v}$ & $\mathbf{x}$ & $\mathbf{v}$ & $\mathbf{v}$ & $\mathbf{v}$ \\
\hline
\end{tabular}


Melalui tabel Tabel 4.13, dapat diketahui bahwa bentuk pemanfaatan yang memilki kriteria sesuai dengan penggunaan optimal BMN idle adalah KSP dan BGS/BSG. Pada dasarnya pemanfaatan dalam bentuk KSP tidak berbeda jauh dengan BGS/BSG, kedua bentuk pemanfaatan tersebut termasuk ke dalam skema Build-Operate-Transfer (BOT) yang umum dilakukan dalam kerja sama pendayagunaan aset maupun penyediaan infrastruktur. Bedanya, bentuk pemanfaatan KSP lebih menitikberatkan pada penerimaan yang akan diperoleh (revenue generating) yaitu PNBP, sedangkan BGS/BSG lebih menitikberatkan pada aset yang akan digunakan/diperoleh untuk kegiatan operasional pemerintah (asset acquisition). BGS/BSG dilakukan atas pertimbangan pengguna barang memerlukan bangunan atau fasilitas guna menyelenggarakan tugas dan fungsi, namun tidak tersedia dana yang cukup untuk penyediaan bangunan dan fasilitas tersebut. Sedangkan KSP dilaksanakan dengan pertimbangan adanya kegiatan optimalisasi namun tidak tersedia dana yang cukup untuk memenuhi biaya operasional, pemeliharaan, dan/atau perbaikan yang diperlukan terhadap BMN.

Berdasarkan analisis di atas, bentuk pemanfaatan yang paling sesuai untuk penggunaan optimal BMN idle di Jalan Letjend Suprapto adalah Kerja Sama Pemanfaatan (KSP), karena bentuk pemanfaatan ini menawarkan pembiayaan, pengembangan, pengoperasian, serta pemeliharaan gedung hasil optimalisasi dalam jangka waktu tertentu dan berfokus pada revenue generating.

\subsection{Potennsi PNBP Yang Mampu Dihasilkan Oleh Eks BMN Idle Atas Penggunaan Optimalnya}

Proses optimalisasi Eks BMN idle di Jalan Letjend Suprapto menggunakan metode HBU menghasilkan keputusan penggunaan optimal berupa ruko dengan bentuk pemanfaatan KSP. Dengan demikian, atas bentuk pemanfaatan KSP negara akan memperoleh penerimaan sebagai berikut:

a) Kontribusi tetap yang dibayarkan setiap tahun, dihitung berdasarkan presentase kontribusi yang besarnya ditentukan oleh perhitungan pengelola barang terhadap nilai wajar BMN idle. Dalam hal penghitungan PNBP atas optimalisasi BMN idle di Jalan Letjend Suprapto, secara matematis dirumuskan sebagai berikut:

Besaran kontribusi tetap $=$ Kt $x$ Nilai wajar $B M N$

b) Bagi hasil (pembagian keuntungan) yang diterima sesuai dengan bagi hasil yang ditentukan dalam perjanjian, dimana besarannya dihitung dengan rumus:

\section{Pembagian Keuntungan $=p \times E G I$ Atau \\ Pembagian Keuntungan $=p \times N P V$}

c) Penerimaan berupa bangunan ruko beserta fasilitasnya sebagai hasil dari pelaksanaan KSP yang diterima sesuai perjanjian atau pada saat berakhirnya perjanjian.

\section{KESIMPULAN DAN SARAN}

\subsection{Simpulan}

1) Eks BMN idle di Jalan Letjend Suprapto, Kecamatan Sumbersari, Kabupaten Jember merupakan salah satu Eks BMN idle di Wilayah Kerja KPKNL Kabupaten Jember yang memiliki potensi tinggi untuk menghasilkan Penerimaan Negara karena lokasinya yang strategis. Eks BMN idle ini terdiri dari tanah seluas $370 \mathrm{~m}^{2}$ dan di atasnya berdiri bangunan bekas rumah dinas seluas $151 \mathrm{~m}^{2}$. Untuk mengetahui potensi atas Eks BMN idle tersebut penulis melakukan analisis untuk tujuan optimalisasi yang meliputi analisis nilai existing Eks BMN Idle, analisis pasar, dan analisis keuangan sehingga terbentuk Highest and Best Use (HBU) atas objek optimalisasi (Eks BMN idle di Jalan Letjend Suprapto).

2) Berdasarkan analisis nilai existing Eks BMN Idle, tanah objek optimalisasi memiliki nilai wajar sebesar Rp4,340,489,000,- sementara bangunan di atasnya karena berada dalam kondisi rusak berat maka diasumsikan tidak memiliki nilai dan justru menimbulkan biaya pembongkaran ketika akan dilakukan pengembangan lahan. Selanjutnya melalui analisis pasar dan analisis kelayakan, diketahui bahwa HBU atas objek optimalisasi adalah sebagai properti komersial berupa ruko. Alternatif ini diproyeksikan menghasilkan NPV sebesar Rp1,159,976,342 sehingga nilai lahan setelah pengembangan diestimasi menjadi sebesar Rp5,500,465,341,-.

3) Melalui identifikasi kesesuaian antara bentuk pemanfaatan dengan penggunaan optimal objek optimalisasi, disimpulkan bahwa bentuk pemanfaatan yang paling sesuai adalah Kerja Sama Pemanfaatan (KSP). Selama masa pemanfaatan, negara akan memperoleh penerimaan berupa kontribusi tetap dan pembagian keuntungan. Dengan demikian, hingga jangka waktu KSP berakhir pemerintah akan memperoleh Penerimaan Negara Bukan Pajak (PNBP) berupa kontribusi tetap, bagi hasil (pembagian keuntungan), dan bangunan ruko beserta fasilitasnya. 


\subsection{Saran}

1) Dalam melakukan analisis pasar, sebaiknya tidak hanya menggunakan data BPS saja, melainkan menggunakan data yang berasal dari wawancara langsung dengan developer atau instansi pemerintah terkait (misalnya Dinas Pekerjaan Umum dan Perumahan, Cipta Karya, dan Tata Ruang).

2) Dalam menentukan data pembanding, sebaiknya dilakukan survei secara langsung pada masingmasing calon pembanding kemudian melakukan penawaran langsung dengan pemilik (melalui telepon atau bertemu langsung).

3) Untuk mendapatkan hasil yang lebih teliti dan maksimal, disarankan untuk mengumpulkan dan menggunakan lebih banyak data pendukung, terutama untuk data analisa finansial.

4) Untuk mendapatkan tingkat diskonto yang lebih mencerminkan Time Value of Money atas investasi properti sebaiknya digunakan metode Band On Investment dengan perkiraan modal yang sesuai.

\section{DAFTAR PUSTAKA (REFERENCES)}

Akmaludin, Utomo, "Analisis Highest And Best Use Pada Lahan Jl. Gubeng Raya", Surabaya, Teknis Pomits, 2013, Volume 2, Nomor 1, (ISSN: 23373539)

Azinuddin, Indryani, "Analisa Highest And Best Use (HBU) Pada Lahan Kosong Nomor 52-58 Di Jalan Dinoyo Surabaya", Surabaya, Jurnal Teknik ITS, 2015, Volume 4, Nomor 2, (ISSN: 2337-3539).

Bayuh, "Optimalisasi Penggunaan Lahan Dengan Metode Penggunaan Tertinggi Dan Terbaik Atau Highest And Best Use (HBU)", Surabaya, 2017.

BPS Kabupaten Jember, "Kabupaten Jember Dalam Angka 2019", Jember, BPS Kabupaten Jember, 2019, (ISSN: 0215.5524)

BPS Kabupaten Jember, "Statistik Daerah Kabupaten Jember", Jember, BPS Kabupaten Jember, 2019.

BPS Kabupaten Jember, "Kabupaten Jember Dalam Angka 2020", Jember, BPS Kabupaten Jember, 2020, (ISSN: 0215.5523)

Diartho, "Ekonomi Regional: Tipologi Dan Sektor Potensial Dalam Pengembangan Wilayah I Studi Pada Wilayah Kecamatan Di Kabupaten Jember)", Jember, Ekonomikawan, 2019, Volume 19, Nomor 1, (ISSN: 1693-7600).

Direktorat Jenderal Keuangan Negara, "Optimalisasi Pemanfaatan BMN: Kontribusi Terhadap Penerimaan Negara", Jakarta, Media Kekayaan Negara, 2017, (ISSN 2089-5836)

Fahrial, Hadi, "Analisis Optimalisasi Pengelolaan Aset Pemerintah Kota Pekanbaru", Dinamika Pertanian, 2020, Edisi Khusus, Nomor 3, (ISSN 0215-2525)
Fanning, "Market Analysis For Real Estate", Appraisal Institute, 2014, Edisi II, (ISBN 978-1-935328-575).

Herradiyanti, Utomo, Putri, "Analisa Penggunaan Tertinggi Dan Terbaik (Highest And Best Use Analysis) Pada Lahan Pasar Turi Lama Surabaya", Surabaya, Jurnal Teknik ITS, 2016, Volume 5, Nomor 2, (ISSN: 2337-3539).

Komite Penyusun Standar Penilaian Insonesia, "Kode Etik Penilai Indonesia (KEPI) Dan Standar Penilaian Indonesia (SPI)", Jakarta, Profesi Penilai Indonesia (MAPPI), 2018, Edisi VII.

Martharina, Wanda, Canadarma, Dkk, "Fasilitas Edukasi Dan Galeri Komunitas Fotografi di Jember", Jember, Jurnal eDimensi Arsitektur, 2016, Volume IV, Nomor 2.

Riyanto, Purnomo, "Eksistensi Barang Milik Negara Berupa Gedung Perkantoran Di Kawasan Komersial: Studi Kasus Di Kawasan CBD Sudirman-Thamrin Jakarta", Tangerang Selatan, Jurnal PKN (Jurnal Pajak dan Keuangan Negara), 2019, Volume 1, Nomor 1.

Siregar, "Manajemen Aset : Strategi Penataan Konsep Pembangunan Berkelanjutan Secara Nasional Dalam Konteks Kepala Daerah Sebagai CEO'S Pada Era Globalisasi \& Otonomi Daerah", Jakarta, Gramedia Pustaka Utama, 2004, (ISBN: 9792207619)

Tedjowidjojo, Mintorogo, (2018). "Rumah Susun Di Jember", Jember, Jurnal eDimensi Arsitektur, 2018, Volume VI, Nomor 1.

Undang-Undang Republik Indonesia Nomor 17 Tahun 2003 Tentang Keuangan Negara.

Undang-Undang Republik Indonesia Nomor 1 Tahun 2004 Tentang Perbendaharaan Negara.

Peraturan Menteri Keuangan Republik Indonesia Nomor 138/PMK.06/2010 Tentang Pengelolaan Barang Milik Negara Berupa Rumah Negara.

Peraturan Menteri Keuangan Republik Indonesia Nomor 246/PMK.06/2014 Tentang Tata Cara Pelaksanaan Penggunaan Barang Milik Negara.

Peraturan Menteri Keuangan Republik Indonesia Nomor 78/PMK.06/2014 Tentang Tata Cara Pelaksanaan Pemanfaatan Barang Milik Negara.

Peraturan Pemerintah Republik Indonesia Nomor 27 Tahun 2014 Tentang Pengelolaan Barang Milik Negara/Daerah.

Peraturan Menteri Keuangan Republik Indonesia Nomor 71/PMK.06/2016 Tentang Tata Cara Pengelolaan Barang Milik Negara Yang Tidak Digunakan Untuk Menyelenggarakan Tugas Dan Fungsi Kementerian Negara/Lembaga. 
ANALISIS OPTIMALISASI EKS BMN IDLE

(Studi Kasus Eks BMN Idle Berupa Tanah Dan Bangunan Rumah Negara Golongan II di J1. Letjend Suprapto No. 31 Jember)

Riska Lailatul Fitri ${ }^{1}$ dan Doni Triono, S.E., M.M. ${ }^{2}$

Peraturan Menteri Keuangan Republik Indonesia 76 /PMK.06/2019 Tentang Perubahan Kedua Atas Peraturan Menteri Keuangan Republik Indonesia Nomor 246/PMK.06/2014 Tentang Tata Cara Pelaksanaan Penggunaan Barang Milik Negara. 